\title{
A Critical Discourse Analysis of Political Ideology and Control Factors in News Translation
}

\author{
Amir Shojaei \\ Department of English, Quchan Branch, Islamic Azad University, Quchan, Iran \\ Email: amir_shojaei66@yahoo.com \\ Fardin Laheghi \\ Department of English, Science and Research Branch, Islamic Azad University, Tabriz, Iran \\ Email: fardin_ls@yahoo.com
}

\begin{abstract}
There are some factors in translating a text which influence the result of translation process, one of which is political ideology and control factors which impose some limitations and give direction to the translator. Through this paper an attempt has been made to substantiate these imposing factors as well as describing the ways translators might apply. Based on critical discourse analysis (CDA) approach to textual analysis and following Lefevere's (1992a; 1992b) concept of patronage, it has been tried to compare some newspaper texts with their related translations so as to depict the role of imposing factors in the process of translation. Results of the survey and analysis of the factors behind the translational aspects indicate that ideologies and political issues are important stimuli which can control the materials being translated, and then presented to the mass through news texts.
\end{abstract}

Index Terms - critical discourse analysis, political ideology, patron, control factors, news translation

\section{INTRODUCTION}

\section{A. Media}

People are affected by what the mass media choose to let them hear, see, and read. Of all the socialization influences that work to shape the skills, values, norms, and behaviors of individuals, the mass media-and among them, news media- appear as one of the most prevalent and powerful. The print and broadcast media are potent in their ability to create and maintain societal perspectives. Through their gate keeping function, they provide what is seen, heard, and read, along with the type and amount of coverage given. Overall, societal thoughts and actions can be influenced by the mass media (as cited in Pedersen, 2002, p. 303).

Mass media outlets have long been considered 'social institutions or domains' in which media discourse conveys the ideologies of members in those institutions (Van Dijk, 1997, p. 28). While media content is regarded as reflective of society, a common belief is that the media conveys 'the dominant elite ideologies' of a social community (Kuo and Nakamura, 2005, p. 394). Such ideologies indicate socio-culturally shared group knowledge, and refer to 'social cognitions shared by members of social groups, organizations, or institutions' (Van Dijk, 1995, pp. 17-18). To conceptualize the ideological domination embedded in mass media, critical discourse analysis (CDA) is one of the approaches often adopted in order to analyze media discourse (as cited in Wang, 2009, pp. 747-48).

\section{B. Translation, Ideology and Rewriting}

Years ago translating a text was supposed to be only rewriting a text by replacing linguistic codes (equivalents) from one language into another. This view was held by linguistic approaches and structuralists, but under the influence of post-structuralism and functionalism, the focus of attention has been shifted to the issue of translator's agency and subjectivity. This subjectivity and influence of the translator, Alvarez and Vidal (1996) claim, will result in realizing the importance of the ideology underlying a translation. They argued that:

...behind every one of the translator's selection, as what to add, what to leave out, which words to choose and how to place them, there is a voluntary act that reveals his history and the socio-political milieu that surrounds him; in other words, his own culture [and ideology] (p. 5).

\section{LITERATURE REVIEW}


In general, Critical Discourse Analysis (henceforth CDA) can be broadly categorized into two research trends - one concerned with representations of news events across different news media platforms, and the other centering on social prejudice and trends of power domination in the social world (Wang, 2009, p. 748).

CDA brings together social theory and textual analysis. Fairclough and Wodak (1997) outlined common tenets of discourse under a critical umbrella to provide a succinct overview of the shared assumptions about discourse held by many within the CDA tradition as:

- Discourse does ideological work.

- Discourse constitutes society and culture.

- Discourse is situated and historical.

- Power relations are partially discursive.

- Mediation of power relations necessitates a socio-cognitive approach.

- CDA is a socially committed scientific paradigm that addresses social problems.

- Discourse analysis is interpretive, descriptive, and explanatory and uses a "systematic methodology."

- The role of the analyst is to study the relationships between texts and social practices (as cited in Rogers et al., 2005, p. 370).

\section{B. Ideology and Power}

The term "ideology" has always been accompanied by its political connotation as it is evident in its dictionary meaning as 'a system of ideas, ideals especially one which forms the basis of economic or political theory and policy' (The New Oxford Dictionary of English, 2005, p.770). Translation scholars who slant in favor of the political definitions of ideology mainly believe that translating itself is a political act. As Tahir Gurcaglar (2003) expressed "translation is political because, both as activity and product, it displays process of negotiation among different agents; on micro-level, these agents are translators, authors, critics, publishers, editors and readers" (p. 113). According to Calzada-Perez (2003) recent definitions of ideology are linked with the concepts of power relations and domination, as she quoted from Eaglton:

"... [Ideology is] ideas and beliefs which help to legitimate the interest of a ruling group or class by distortion or dissimulation" (p. 4).

If we accept the definition of ideology as "an action-oriented set of beliefs" (Seliger, as cited in Irland, 1989, p. 131) and if we assume those beliefs, even where they call themselves aesthetic, religious or poetic, to be political in the sense that their application establishes relation of dominance, then we can see how as Fawcett said, throughout the centuries "individuals and institutions have applied their particular beliefs to the production of certain effects in translation" (Baker, 1998, p. 107).

Moreover, the questions Nord (1991, p. 36) asked about a specific text to be translated can be asked of translation in general, but with a power orientation. Then as a result we can ask such questions as:

1) What gets translated?; i.e. what is valued and what is excluded,

2) Who does the translation?; i.e. who controls the production of translation,

3) Who is translated for?; i.e. who is given access to foreign materials and who denied,

4) How is the material translated?; i.e. what is omitted, added or altered to control the message.

These power relations are also discussed in one of Lefevere's (1992b) control factors that he calls it Patronage, mentioning:

Translators tend to have relatively little freedom in their dealing with patrons, at least if they want to have their translations published..... Patrons can encourage the publication of translations they consider acceptable and they can also quite effectively prevent the publication of translations they do not consider so (p. 19).

He (1992a, p. 9) also distinguished between three factors which control the function of every translation in the literary system as follows:

1) Professionals within the literary systems

2) Patronage outside the literary system

3) The dominant poetics.

In this part it should also be mentioned that the main focus of this paper is mainly on the second factor (patronage outside the literary system) which Lefevere explained it as "the powers (persons, groups, institutions) that can further or hinder the reading, writing, and rewriting of literature" (ibid: 12).

Patrons can vary from a simple directing individual to a complicated group of people, institutions, and regions and finally at the extreme end even a society. Here are some examples of such patrons controlling a translation:

a) An influential and powerful individual in a given historical era (e.g. Elizabeth I in shake spear's England, Hitler in 1930s Germany, etc.);

b) Groups of people (publishers, the media, a political class or party);

c) Institutions which regulate the distribution of literature and literary ideas (national academies, academic journals and, above all, the educational establishment).

Lefevere categorized three elements to this patronage identifying them as:

- The ideological component: This constrains the choice of subject and the form of its presentation. He regards patronage as being basically ideologically focused. 
- The economic component: This concerns the payment of writers and rewriters. In the past, this case was in the form of a pension but nowadays, it is more likely to be royalty payments and translator's fees. Translators are paid by newspaper publishers, universities and even in some cases by governments.

- The status component: This occurs in many forms. In return for payment the translator receives he is often expected to conform to the patron's expectations. Similarly, membership of a particular group involves behaving in a way conductive to supporting that group; e.g. when a person is working for a specific party then he must consider the ideologies and basics of that party and so translate the texts in a way that his translation satisfies the seeks of that dominant patron (which here it is the party paying the money). In this manner the status of the patrons in the society is kept as they wish (ibid: 16).

The patron's efforts are directed at maintaining the stability of the system. So the translator will try to translate in the patron's favor. These power relations exist in many news translations in recent years but they have hardly been studied so far. This paper presents a case study by comparing some ST news texts with their translated TT equivalents in order to substantiate the influence of political ideology and patronage in translating such texts. Moreover, some other sociocultural aspects will be analyzed as well.

\section{Linguistic Toolkit for CDA}

The CDA approach takes the view that any aspect of linguistic structure could be ideologically significant. Fowler (1991) introduces the linguistic 'tools' for critical studies, such as the analysis of transitivity in syntax, lexical structure, modality, and speech acts. Previous studies have also found that certain areas of language (i.e. lexicon and syntactic structure) are particularly implicated in encoding social values and beliefs (Fairclough, 1989, 1995; Fang, 1994; Min, 1997; Teo, 2000; Van Dijk, 1991, 1988; Wang, 1993, as cited in Kuo and Nakamura, 2005, p. 403).

So, linguistic categories for analytical work are important in CDA, because through linguistically-oriented discursive analyses it is possible to relate texts to their (inter)contexts and to their broader social frameworks. In addition, there are a number of discursive strategies such as presuppositions (Mazid, 2007), intertextualization (Cameron, 2007), political implicatures (Van Dijk, 2005), and, in general, manipulations (Chilton, 2005; Van Dijk, 2006) which are among the most frequent strategies used by the researchers (my emphasis) (as cited in Resende, 2009, p. 372; Gavriely-Nuri, 2010, p. 569).

\section{Lexicalization}

Lexicalization is one of the linguistic toolkits for textual analysis in CDA. As van Dijk (1998) suggests, 'opinions may be conventionalized and codified in lexicon' (p. 205), therefore, some words may be used to convey particular negative or positive meanings and implications about ingroup or outgroup members which may have an ideological basis (Martínez-Roldán and Malavé, 2004, p. 165).

Lexicalization, or word choice, is 'the major dimension of [ideologically controlled] discourse meaning' (Van Dijk, 1995, p. 259). Lexical analysis distinguishes among subtle shades of meaning. To clarify the point, Anon (1985, p. 1066) provides a good example where the sentence 'Black teens burglarized the store' is different from, 'Black teens robbed the store.' Burglarizing implies entering unlawfully with intent to steal; robbing implies stealing under threat of force or violence. Thus, the word 'robbed' constitutes a more powerful indictment, because it connotes that the teens threatened to injure or kill someone (thus causing potentially irretrievable loss) rather than causing the loss of property (which can be replaced). Using 'robbed' is thus more consistent with racial ideological thinking that justifies social control of black deviants because of the alleged threat that they pose to white (and other) innocents (as cited in Johnson et al., 2010, p. 248). Following the mentioned manner of analysis, lexicalization is the main linguistic tool for the textual analysis of the present study.

\section{METHODOLOGY}

Some news texts from the WALL STREET JOURNAL (18th of May, 2010) and their translation into Farsi done by JAAM-E-JAM newspaper (19th of May, 2010) have been selected to be compared. The time available for translating these texts was only one day. It should also be mentioned that JAAM-E-JAM is a Persian government-dependant newspaper obliging its translators and staff work and write in favor of the Iranian government and at the same time against some western and American states. The study is conducted in word level, sentence level and finally in discourse level. The results are mostly qualitative and need the readers' own interpretations too.

\section{ANALYSIS}

Now we are going to cite some excerpts from the mentioned sources analyzing different aspects of the translation direction and the role of patronage in the process of conveying the message from a specific source into another one by completely different ideologies:

1) WALL STREET (ST) writes: 
.... made irrelevant 16 months of President Obama's "diplomacy."

$J A A M-E-J A M(\mathrm{TT})$ translates:

\section{بعد از 16 ماه فثار روانى و دييلماسى ، اوياما شكست خورده است}

\section{Back-translation of TT:}

...after 16 months of mental pressure and using diplomacy Obama is now defeated.

As it can be seen in the source text there is no reference to "فثار روانىى (mental pressure) which is an additional adjective phrase. Besides, the verb of the sentence (made irrelevant) according to Oxford Advanced Learner's Dictionary means "Make: cause to be - Irrelevant: not important or connected with a situation".

But it is clear that the translator has used the adjective "شكست خورده" (defeated) for this verb reinforcing the negative aspect of the story. Besides, even if the verb of the source text has an implied meaning of defeat, then the target text is obliged to translate it in an implied manner. Although there is just a trifle difference in the meaning of ST and TT and we can't regard it as a kind of mistranslation, but it is clear the translator has used the more explicit and negative form in order to show the situation of the enemy country worse than what it is in reality. This is a kind of impression that a patron might have on the translator.

This can be a good example for the case where Lefevere (1992a) expressed:

Translation is produced on the basis of an original text with the intention of adapting the original to a certain ideology or poetics of a different audience, and it is an activity performed under constraints of patronage, poetics and ideology initiated by the target systems, as such it is an act of rewriting of an original text to conform to certain purposes instituted by the receiving system (p. vii).

2) WALL STREET (ST) writes:

The deal is a political coup for Tehran and possibly delivers the coup de grace to the West's half-hearted efforts to stop Iran from acquiring a nuclear bomb.

$J A A M-E-J A M(\mathrm{TT})$ translates:

اين يك كودناى سياسى براى شكست خو استه غربى ها در خصوص توقف برنامه هسته اي ايران است.

Back-translation of TT:

This is a political coup to frustrate the pleas of the western countries to stop the Iranian nuclear programs...

It is crystal clear that in this part the translator has altered the theme of the utterance for a specific predefined concept imposed to him by the patron that supports him economically (which here it is the Iranian government); i.e. while the Iranian (and specially the Iranian government) call their nuclear efforts peaceful, the western countries assume that Iran is trying to use this technology in a non-peaceful way and finally make a nuclear bomb. So it is not surprising that the translator has used the humanized and positive collocation of "برنامه هسته ایى" (nuclear program) instead of the savagelooking and negative collocation of "بمب هسته ایى" (nuclear bomb).

In this way the translator tries to legitimate the Iranian right to use nuclear energy as well as fossilizing the idea that the Iranian use of nuclear energy is a peaceful activity and not a source of danger for the world. Moreover, while the ST tries to impede Iran from making a nuclear bomb, the presented translation also implies the meaning that the westerns countries are trying to stop Iran from an incontrovertible right (using nuclear energy in a peaceful manner). So we can claim that it is the patron's influence which makes translators modulate such phrases and replace the collocations which are acceptable according to the patron's attitudes and code of rules.

This example shows that different languages reflect different values and cultures [and ideologies]; it is based on this delicate principle that Lefevere (1999) in an attempt to mediate different languages, values or cultures, put:

"...translations nearly always contain attempts to naturalize the different culture to make it conform more to what the reader of the translation is used to" (p. 237).

Therefore as a result of such imposing factors it can be said that translations are rarely equivalent to the original.

3) WALL STREET (ST) writes:

$J A A M-E-J A M(\mathrm{TT})$ translates:

"امروزه ديبلماسى فاتح ميدان است ." اين سخن را رئيس جمهور برزيل با كنايه به دولت اوباما بيان كرد و به دولت اوباما نشان داد كه در سياست خارجى كاملا در مقابل وي قر دار دار دارد.

Back-translation of $T T$ :

"Diplomacy emerged victorious today." Brazilian president expressed in an ironic form to Obama's government showing Obama's government that he is in complete disaccord with him in foreign policy. 
Here the last part of the translated text which has no equivalent in the source text has been added by translator's own intention. The exact general meaning of ST is that "the Brazilian president uses Obama's own most important foreignpolicy principle against Obama himself; i.e. he says something to Obama that it is originally Obama's own statement.

But we can witness that the translator in a way has tried to show that Brazilian president is not in accord with Obama at all. The digestion of this concept needs some extra-linguistic and political definitions; the patron (here the Iranian government) wants to show that Brazil is an ally of Iran and so it defends Iranian ideologies that are completely different from the American ones. To achieve this aim the translator has manipulated the ST material skillfully in a way that the translated text implies "Brazilian and American presidents are two people who don't concur with each other". In this way translator implies that Brazil is a friend of Iran as well as being an enemy of Unite Stats.

According to Lefevere (1992a) and as it was shown in this example the process of translating a text is an affair which is "carried out in the service of power" (p. vii) and the translator is obliged to obey the patron's orders and take his directions for some reasons. Regarding this issue Lefevere (ibid: 16) mentioned three reasons that cause translators to work for the patrons:

- An "economic component" on which the translator depends for his or her living (money for life)

- An element of "status" of which could lead to elevating the translator's reputation (fame and reputation)

- An "ideological component" which restricts the act of translating (translating according to norms of the society).

4) WALL STREET writes:

After 16 months of his extended hand and after downplaying support for Iran's democratic opposition, Mr. Obama now faces an Iran much closer to

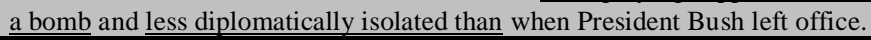

$J A A M-E-J A M$ translates:

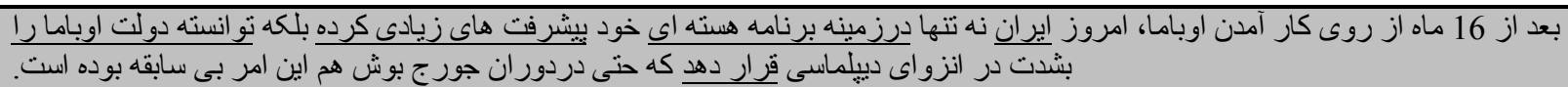

Back-translation of TT:

Now after 16 months of Obama's taking office not only Iran has made a great progress in its nuclear program but also it has severely isolated Obama's government diplomatically. This is a phenomenon which didn't take place even in President Bush's term.

By a close scrutiny of the underlined parts and comparing them with each other it gets crystal clear that the translator has changed the voices of sentences in a way that the causative aspect of the story has completely been changed in favor of Iran (which here is the patron). To achieve this aim, two phrases "extended hand" and "support for Iran's democratic opposition" have been omitted in the translated text. Moreover, the sentence "Mr. Obama now faces an Iran much closer to a bomb" has intentionally been translated into "an Iran much progressed in its nuclear program."

Another delicate point to be mentioned here is that the translation has used the sentence "make Obama more diplomatically isolated" for the ST adjective phrase "less diplomatically isolated (Iran)". In this way the translator has tried to change the Iran's position from a non-agent character to an agent one which powerfully can control the situation.

Here comes the discussion of "translators as traitors" expressed by Lefevere (1992a) where he claims:

"Hence rewriters/translators are in some aspects, traitors, since to a certain extent they violate the original, which they must do to remain within the boundaries of the target culture [and ideologies]..." (p. 13).

Besides, Venuti (1998) also mentions that translators have the power to influence and impress the society and literature, since translation has "far-reaching social effects" (p. 81).

\section{RESULTS}

Based on the examples scattered throughout the different pages of the paper, we can conclude that as Bloor and Bloor (2007) noted, an aspect of ideology can be carried "even by a single word" (p. 11). It was shown that even a shift of voice or adding or omitting a single word may cause a change in meaning as we described them in the case of such examples as:

- Using "nuclear program" instead of "nuclear bomb",

- Using "defeated" instead of "make irrelevant",

- Adding " فشار روانى" (mental stress) to the translation

Through a textual analysis and mainly following the lexicalization tool for a critical discourse analysis (CDA) of texts, it was also shown that intentional and purposeful changes in word orders of sentences, or even the shift of sentence orders in a paragraph sometimes cause a complete shift in meaning. These conscious and purposeful shifts are imposed to the translators by some control factors which may be some governments, political parties or publishers, etc. or even it might be a personal ideology of the person himself.

Moreover, there are lots of news texts which are translated in different cultures and societies that can be studied according to their common beliefs and political thoughts. The study of such cases can prove the fact that different ideologies and control powers can change the whole meanings of texts translated by some translators under the 
impression of a patron. Translation therefore takes the form of rewriting that is carried out within the framework of the target language, culture and ideology in the service of a control factor wielded by the patron or the receiving system.

\section{REFERENCES}

[1] Alvarez, R. \& Vidal, M.C. (1996). Translating: A Political Act' in R. Alvarez \& M.C. Vidal (Ed.) Translation, Power, subversion. Philadelphia: Multilingual Matters.

[2] Anon (1985). The American Heritage Dictionary. New York: Houghton Mifflin.

[3] Baker, M. (1998). Routledge Encyclopedia of Translation Studies. London: Routledge.

[4] Bloor, M. \& Bloor, T. (2007). The Practice of Critical Discourse Analysis. London: Hodder Arnold.

[5] Calzada-Perez, M. (2003). Apropos of Ideology. Manchester: St. Jerome.

[6] Gavriely-Nuri, D. (2010). The idiosyncratic language of Israeli 'peace': A Cultural Approach to Critical Discourse Analysis (CCDA). Discourse \& Society, 21(5): 565-585.

[7] Fairclough, N., \& Wodak, R. (1997). Critical discourse analysis. In T. van Dijk (Ed.), Discourse as social interaction (pp. 258284). London: Sage.

[8] Fowler, R. (1991). Language in the News: Discourse and Ideology in the Press. London: Routledge.

[9] Johnson, K.A., Sonnett, J., Dolan, M. K., Reppen, R. \& Johnson, L. (2010). Interjournalistic discourse about African Americans in television news coverage of Hurricane Katrina. Discourse \& Communication, 4(3): 243-261.

[10] Kuo, S. \& Nakamura, M. (2005). Translation or Transformation? A case study of language and ideology in the Taiwanese press. Discourse and Society, 16(3): 393-418.

[11] Lefevere, A. (1992a). Translation, Rewriting, and the Manipulation of Literary Fame. London/New York: Routledge.

[12] Lefevere, A. (1992b). Translation/ History /Culture: A Sourcebook. New York: Routledge.

[13] Lefevere, A. (1999). 'Mother Courage's Cucambers: Text, System and Refraction in a Theory of Literature', in Larence Venuti (Ed) the Translation Studies Reader, London: Routledge.

[14] Martinez-Roland, C. M. \& Malave, G. (2004). Language Ideologies Mediating Literacy and Identity in Bilingual Contexts. Journal of Early Childhood Literacy, 4(2): 155-180.

[15] Nord, Ch. (1991). 'Text Analysis in Translation' in M. Baker (Ed.) Routledge Encyclopedia of Translation Studies. London: Routledge.

[16] Pedersen, P. M. (2002). Examining Equity in Newspaper Photographs: A Content Analysis of the Print Media Photographic Coverage of Interscholastic Athletics. International Review for the Sociology of Sport, 37:3-4; 303-318.

[17] Resende, V. (2009). It's not a matter of inhumanity': a critical discourse analysis of an apartment building circular on 'homeless people. Discourse \& Society, 20(3): 363-379.

[18] Rogers, R., Malancharuvil-Berkes, E., Mosley, M., Hui, D. \& Joseph, G. O. (2007). Critical Discourse Analysis in Education: A Review of the Literature. Review of Educational Research, 75(3): 365-416.

[19] Tahir-Gurcaglar, S. (2003). 'The Translation Bureau Revisited: Translation as Symbol' in M. Calzada-Perz (Ed.) Apropos of Ideology. Manchester: St. Jerome.

[20] Van Dijk, T.A. (1995). Discourse Semantics and Ideology. Discourse \& Society 6(2): 243-89.

[21] Van Dijk, T.A. (1997). 'Discourse as Interaction in Society', in T.A. van Dijk (ed.) Discourse as Social Interaction, pp. 1-37. London: Sage.

[22] Venuti, L. (1998). Scandals of Translation: Towards and Ethics of Difference. London: Routledge.

[23] Wang, H. C. (2009). Language and Ideology: gender stereotypes of female and male artists in Taiwanese tabloids. Discourse \& Society, 20(6): 747-774.

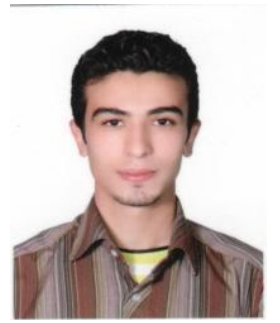

Amir Shojaei was born in Tabriz, Iran, 1987. He is an M.A. candidate of Translation Studies at Azad University of Quchan, Iran. He lives in Tabriz and received his B.A. in the field from Azad University of Tabriz, Iran in 2009. Besides teaching various courses of EFL at some English institutes, he does some practical translational affairs from English to Persian for a number of newspapers largely including political and journalistic texts. His main areas of interest include Critical Discourse Analysis, Political Discourse, News Analysis and Media Representation.

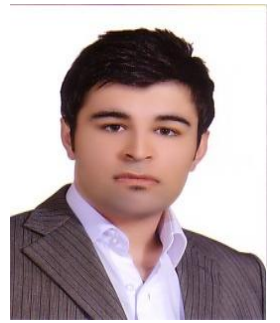

Fardin Laheghi was born in Tabriz, Iran, 1986. He is an M.A. candidate of Translation Studies at Science and Research University of Tabriz, Iran. He lives in Tabriz and received his B.A. in the field from Azad University of Tabriz, Iran in 2009. His main areas of interest include Political Discourse and CDA. 